\title{
Intracoelomic pressure and coelomic perfusion pressure in healthy tegus (Salvator merianae)
}

\author{
André Nicolai Elias da Silva ${ }^{1}$ Thais Feres Bressan ${ }^{1}$ Adriano Bonfim Carregaro ${ }^{1^{*}}$
}

'Departamento de Medicina Veterinária, Faculdade de Zootecnia e Engenharia de Alimentos (FZEA), Universidade de São Paulo (USP), 13635-900, Pirassununga, SP, Brasil. E-mail: carregaro@usp.br. "Corresponding author.

\begin{abstract}
The evaluation of intracoelomic pressure is very important, as many diseases can culminate with an increase in intracoelomic pressure and a consequent reduction in perfusion of the abdominal organs. The aim of this study was to measure the intracoelomic pressure and coelomic perfusion pressure in tegus (Salvator merianae). Twelve healthy tegus without sexual distinctions, weighing $1.64 \pm 0.39 \mathrm{~kg}$, were enrolled in this study. Intracoelomic pressure was measured using two methods: a handmade water column system and a pressure transducer connected to a multiparameter monitor. Coelomic perfusion pressure was determined by subtracting the intracoelomic pressure from the mean arterial pressure, which was measured using an oscillometric method. Intracoelomic pressure was 0mmHg (range, 0 - 0.5) according to the water column method and $2 \mathrm{mmHg}$ (range, $0-2.0$ ) according to the pressure transducer. Coelomic perfusion pressure was $76 \mathrm{mmHg}$ (range, $62-105$ ) according to the water column system and 82 mmHg (range, 57 - 93) according to the pressure transducer. No significant difference was observed between the values obtained by the different measurement methods. Intracoelomic pressure value reported in this study might be useful in tegus, but the coelomic perfusion pressure should be used with caution, considering the blood pressure method that was used. Key words: coelomic perfusion pressure; compartment pressure; lizards; reptiles.
\end{abstract}

Mensuração da pressão intracelomática e da pressão de perfusão celomática em teiús saudáveis (Salvator merianae)

RESUMO: A pressão intracelomática é um importante parâmetro, uma vez que muitas doenças culminam com o aumento da pressão intracelomática e consequentemente na redução da perfusão dos órgãos abdominais. Oobjetivo do estudo foi mensurar a pressão intracelomática

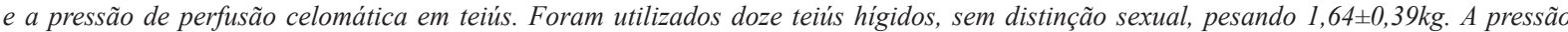
intracelomática foi determinada pelo sistema de coluna de água e por um transdutor de pressão conectado a um monitor multiparamétrico. Já a pressão de perfusão celomática foi determinada pela subtração da pressão intracelomática do valor da pressão arterial média, sendo este obtido pelo método oscilométrico com o manguito posicionado na base da cauda. A pressão intracelomática mensurada pelo sistema de coluna de água foi $\mathrm{OmmHg}[0-0,5]$ e pelo transdutor de pressão foi $2 \mathrm{mmHg}$ [0 - 2,0]. A pressão de perfusão celomática obtida pelo sistema de coluna de água foi $76 \mathrm{mmHg}$ [62 - 105] e pelo transdutor de pressão foi 82 $\mathrm{mmHg}$ [57 - 93]. Não foram detectadas diferenças estatísticas entre os métodos de mensuração. Os valores de pressão intracelomática obtidos podem ser úteis para avaliação clínica em teiús, mas os valores de pressão de perfusão celomática devem ser utilizados com cautela, a considerar o método de mensuração da pressão arterial.

Palavras-chave: lagartos; pressão compartimental; pressão de perfusão celomática; répteis.

\section{INTRODUCTION}

The class Reptilia is one of the most diverse classes of vertebrates, composed of more than 9,500 species divided into four orders. Animals of the suborder Lacertilia, represented by more than 3,000 species of lizards, currently play an important role in zoological collections. Among them, the tegu (Salvator merianae) is described as one of the most widespread South American species (STAHL, 2003). Moreover, it is currently among the 10 species of reptiles most often forwarded to wildlife recovery centers in Brazil (FREITAS et al., 2015). Veterinary care of reptiles is usually necessary due to trauma, dystocia, coelomitis, pneumonia, cloaca prolapse, oviduct, or hemipenis (BARTEN, 2006), all culminating in increased pressure within the coelomic cavity.

Intracoelomic pressure variation is directly related to coelomic perfusion pressure. An increase in intracoelomic pressure may lead to coelomic perfusion pressure reduction, and consequently to organ ischemia. Despite its relevance in critical care patients this 
parameter is poorly measured in such conditions. Similar to intra-abdominal pressure, intracoelomic pressure can be defined as the result of a force generated within a delimited compartment. In mammals, the abdominal cavity may be considered a closed chamber filled with organs and surrounded by rigid structures such as the vertebrae and pelvis, and flexible structures such as diaphragm and abdominal musculature. The relationship of the force generated by these static components can be defined as intra-abdominal pressure (MALBRAIN et al., 2006), and it is also closely related to hemodynamic and ventilatory changes (RICHARDSON \& TRINKLE, 1976; JAPIASSÚ et al., 2007).

Patients with sustained elevation of intraabdominal pressure may develop intra-abdominal hypertension (JAPIASSÚ et al., 2007; JOUBERT et al., 2007). Intra-abdominal hypertension can trigger substantial systemic changes related to undesirable effects on cardiovascular function due to the compression of vascular plexuses, resulting in preload and cardiac output reduction and an increase in afterload. Harmful pulmonary effects occur by displacement of the diaphragm and consequent increase of ventilatory effort. Renal function may also be affected, leading to oliguria and, in severe cases, anuria (HUNTER \& DAMANI, 2004; BALL et al., 2008). Increase in intracavitary pressure, such as that due to urinary retention, generates mechanical pressure that impairs venous and arterial perfusion of the organs (HUNTER \& DAMANI, 2004; BALL et al., 2008).

Another significant parameter in this context is abdominal perfusion pressure, calculated by subtracting intra-abdominal pressure from mean arterial pressure (MAP). Abdominal perfusion pressure correlates the effects of intracavitary pressure on capillary perfusion pressure, suggesting a possible hypoperfusion of abdominal organs such as the kidneys, liver, and intestines (HUNTER \& DAMANI, 2004; MALBRAIN, 2004; BALOGH \& MOORE, 2005; LUI et al., 2007; AN \& WEST, 2008; SCHEPPACH, 2009). Despite this relative importance, intra-abdominal pressure measurement is still seldom used in human or veterinary medicine; data available in animals are only from dogs and horses (JAPIASSÚ et al., 2007; JOUBERT et al., 2007; MUNSTERMAN \& HANSON, 2009; GONÇALVES et al., 2011). The present study measured and compared the intracoelomic pressure and the coelomic perfusion pressure in tegus by two different methods to estimate the normal values for the species.

\section{MATERIALS AND METHODS}

Twelve healthy tegus with no sexual distinction (body weight, $1.64 \pm 0.39 \mathrm{~kg}$ ) from the
University's lizard husbandry facility were included in this study. The animals were maintained under $12 / 12 \mathrm{~h}$ lighting conditions, an air temperature of $26-29^{\circ} \mathrm{C}$, and $50 \%$ relative humidity. They received ground meat enriched with calcium and vitamin D every two days and water ad libitum.

To measure the intracoelomic pressure, the animals underwent food fasting for seventy-two hours, and then they were physically restrained and positioned in left lateral recumbency. The intracoelomic pressure was measured using two methods. A 20-G catheter (Solidor $^{\circledR}$, Barueri, SP, Brazil) was introduced into the coelomic cavity and placed $2 \mathrm{~cm}$ above the pelvic limb on the transition line between the lateral and the ventral scales. After catheter insertion, the animals were maintained in ventral recumbency. The catheter was connected to a handmade water column system filled with heparinized saline (Figure 1A), or to a multiparameter monitor (LW8, Life Window Lite, Digicare $^{\circledR}$, Boynton Beach, FL, USA) via a pressure transducer filled with heparinized saline (Figure 1B). Intracavitary administration of $1 \mathrm{~mL} / \mathrm{kg}$ of $0.9 \% \mathrm{NaCl}$ was conducted, and the return pressure of this volume was the intracoelomic pressure. Before measurement, both systems were zeroed at the mid-level of the abdomen. Results from the water column system were converted to $\mathrm{mmHg}\left(\mathrm{cmH}_{2} \mathrm{O} / 1.36\right)$, and there was a 15-day interval between the two measurements.

Non-invasive measurement of MAP was performed using an oscillometric device (LW 8, Life Window Lite, Digicare ${ }^{\circledR}$ ). A cuff standardized to $40 \%$ of the circumference of the tail (BRESSAN et al., 2016) was placed over the base of the tail. Coelomic perfusion pressure was obtained by subtracting the intracoelomic pressure value from MAP.

Statistical analysis was performed using GraphPad Prism $7^{\circledR}$ (GraphPad Software, Inc., La Jolla, CA, USA). The normality distribution of the data was evaluated with the Shapiro-Wilk test. A paired t-test was used for parametric data (MAP). Results are shown as mean \pm standard deviation. For nonparametric data (intracoelomic pressure and coelomic perfusion pressure), a Wilcoxon rank sum test was applied. Results are shown as the median (minimum-maximum). $\mathrm{P}<0.05$ was considered significant.

\section{RESULTS}

No statistical difference was observed between the measurement methods. The intracoelomic pressure obtained by the water column was $0 \mathrm{mmHg}(0-$ $0.5)$ and by the pressure transducer was $2 \mathrm{mmHg}(0-2.0)$ $(\mathrm{P}=0.06)$. The MAP obtained at each measurement was 


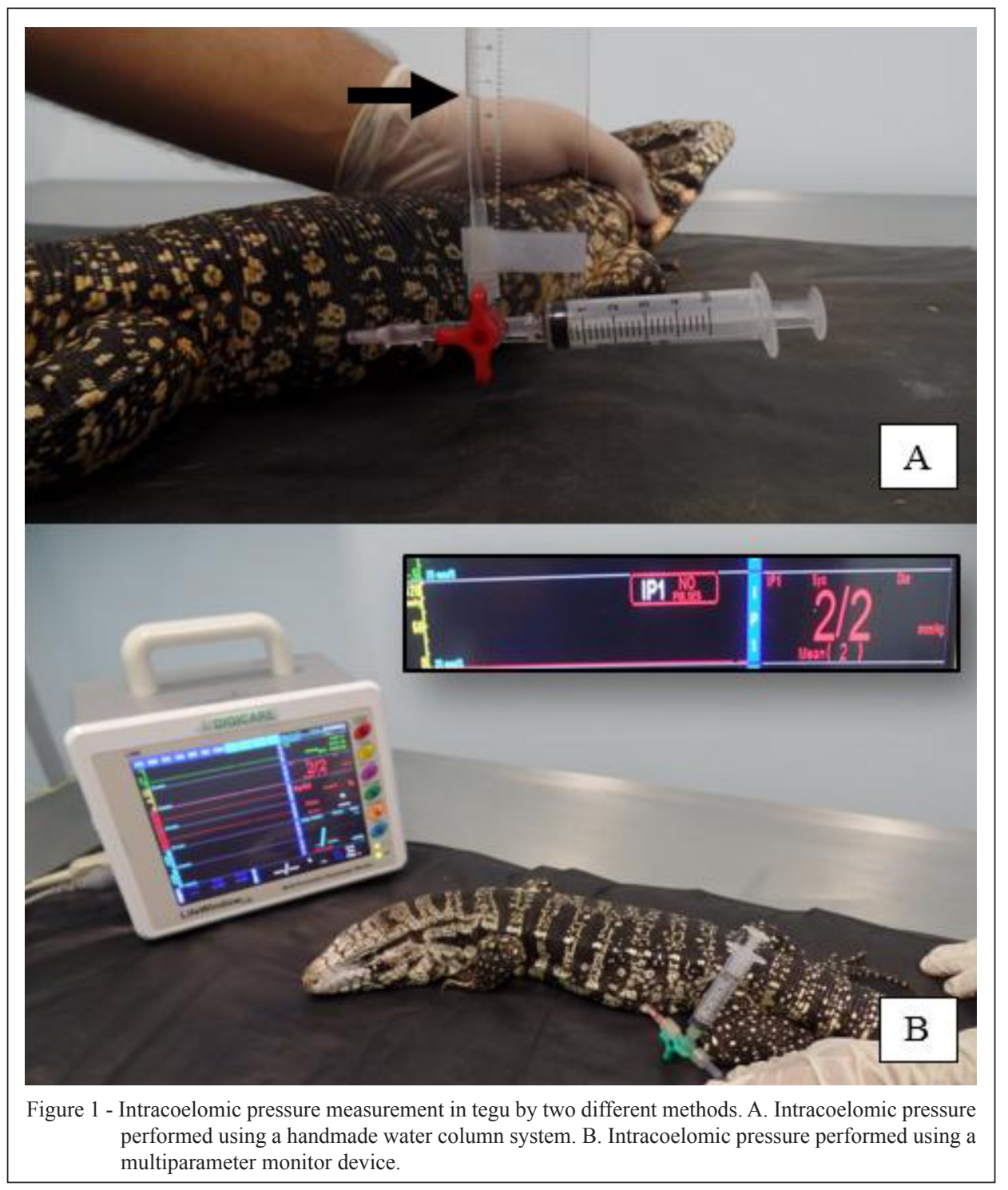

$77 \pm 10 \mathrm{mmHg}$ with a water column and $82 \pm 12 \mathrm{mmHg}$ with a pressure transducer $(\mathrm{P}=0.35)$. The coelomic perfusion pressure was $76 \mathrm{mmHg}(62-105)$ according to the water column system and $82 \mathrm{mmHg}(57-93)$ according to the pressure transducer $(\mathrm{P}=0.56)$. Intracoelomic pressure showed a power of $93 \%$, whereas coelomic perfusion pressure $(55 \%)$ and MAP $(24 \%)$ showed an insufficient power analysis $(<80 \%)$.

\section{DISCUSSION}

A significant amount of critical care in reptiles may show changes in intracoelomic pressure, with possible repercussions in coelomic perfusion pressure (STAHL, 2003; MARTINEZ-JIMENEZ \& HERNANDEZ-DIVERS, 2007; RIVERA, 2008; SYKES, 2010). An increase in intra-abdominal pressure in humans is directly related to morbidity and mortality (HONG et al., 2002), primarily due to the generation of abdominal compartment syndrome that impairs organ perfusion (MARSHALL et al., 1995; SAGGI et al., 1998).

The measurement of intracoelomic pressure in tegus was performed using a transducer pressure, which is considered the gold standard method in human and veterinary medicine despite its invasiveness (SCHACHTRUPP et al., 2003; MALBRAIN, 2004; RISIN et al. 2006; SMITH \& SANDE, 2012). When 
considering this information and the lack of information available on the intracoelomic force in tegus, the method of insertion of a coelomic catheter proved to be a good choice. In addition, anatomical features such as the presence of a cloaca invalidated the use of indirect techniques, which are performed by probing the urinary bladder, uterus, or colon, and measured by the pressure transduction endured by these organs. The volume used for the measurement of intracoelomic pressure in tegus corresponds with that used by authors who measured this parameter in humans (MALBRAIN \& DEEREN, 2006; JAPIASSÚ et al., 2007) and small animals (RABELO \& ZORZELLA, 2012).

The purpose of the fasting period was to reduce the influence of food intake on intracoelomic pressure, since the addition of anything to a delimited cavity may alter the pressure (MALBRAIN et al., 2006). Although, apparently prolonged, the fasting time is commonly recommended for this species (KLEIN et al., 2006).

To the authors knowledge, the intracoelomic pressure and coelomic perfusion pressure values obtained for Salvator merianae in the present study are the first described, and these results have also not been measured in other species of reptiles. Therefore, the results of the present study may be used for the species and as a basis for future studies.

There was no significant difference between the intracoelomic pressure values obtained by the two methods, which makes both techniques feasible for measurement of this parameter. However, it must be emphasized that measurement using the pressure transducer is less affected by human interference in clinical practice, and the values should be more reliable compared to values obtained using the water column method.

A post-hoc power analysis was also performed, and the power was calculated with $\alpha=.05$ and 12 repetitions as experimental number $<$ www. stat.ubc.ca/ rollin/stats/ssize/n1.html>, August, 31 2017). The power analysis shown that the number of animals enrolled were adequate for detect a statistical difference in intracoelomic pressure between the two groups, but it was not for MAP and coelomic perfusion pressure. This can be explained by the MAP values, which are required for calculation. This poor power might be due to the low reliability of noninvasive blood pressure measurement, especially by the oscillometric method (CHINNADURAI et al., 2010). The authors suggest that the power of coelomic perfusion pressure would improve if an invasive blood pressure method was used, but this procedure is not feasible in clinical conditions according to the authors' experience.

\section{CONCLUSION}

There is no difference between intracoelomic pressure and coelomic perfusion pressure obtained by the water column technique or the invasive blood pressure monitor. The intracoelomic pressure value might be useful for veterinarians specializing in reptiles, but the coelomic perfusion pressure values should be used with caution, considering the blood pressure method that was used.

\section{BIOETHICS AND BIOSSECURITY COMMITTEE APPROVAL}

Institution's research ethics committee Faculdade de Zootecnia e Engenharia de Alimentos (FZEA) of Universidade de São Paulo (USP) (141477740), and by the Instituto Chico Mendes de Conservação da Biodiversidade (44767-2).

\section{ACKONOWLEDGMENTS}

The authors would like to thank Fundação de Amparo a Pesquisa do Estado de São Paulo (FAPESP) (2014/10452-9) and Conselho Nacional de Desenvolvimento Científico e Tecnológico (CNPq) (304566/2015-2) for research support.

\section{REFERENCES}

AN, G.; WEST, M.A. Abdominal compartment syndrome: a concise clinical review. Critical Care Medicine, v.36, n.4, p.1304-1310, 2008. Available from: <https:/www.ncbi.nlm.nih.gov/pubmed/18379259>. Accessed: Mar 23, 2017. doi: 10.1097/CCM.0b013e31816929f4.

BALL, C.G. et al. The secondary abdominal compartment syndrome: not just another post-traumatic complication. Canadian Journal of Surgery, v.51, n.5, p.399, 2008. Available from: $<$ https://www.ncbi.nlm.nih.gov/pmc/ articles/PMC2556543/>. Accessed: Mar 23, 2017. doi: PMC2556543.

BALOGH, Z.; MOORE, F.A. Intra-abdominal hypertension: not just a surgical critical care curiosity. Critical Care Medicine, v.33, n.2, p.447-449, 2005. Available from: <https://www.ncbi.nlm.nih. gov/pubmed/15699854>. Accessed: Mar 23, 2017. doi: 15699854.

BARTEN, S.L. Lizards. In: MADER, D.R. Repitile medicine and surgery. $2^{\text {a }}$ ed. Saunders Elsevier. EUA, p. 59-77, 2006.

BRESSAN, T.F. et al. Comparison between invasive and oscillometric methods formeasurement of blood pressure in tegus (Salvator merianae). In: XII CONGRESSO BRASILEIRO DE ANESTESIOLOGIA VETERINÁRIA, 2016, Curitiba, PR. Anais... V.1, p.85.

CHINNADURAI, S.K. et al. Comparison of an implantable telemetry device and an oscillometric monitor for measurement of blood pressure in anaesthetized an unrestrained green iguana. Veterinary Anesthesia an Analgesia, v. 37, n. 5, p.434-439. Available from: $<$ https://www.ncbi.nlm.nih.gov/pubmed/20712610>. Accessed: Aug 31, 2017. doi: 10.1111/j.1467-2995.2010.00557.x.

FREITAS, A.C.P.D. et al. Diagnosis of illegal animals received at the wildlife rehabilitation center of Belo Horizonte, Minas Gerais State, Brazil in 2011. Ciência Rural, v.45, n.1, p.163-170. 2015. 
Available from: $<$ http://www.scielo.br/scielo.php?script=sci_artt ext\&pid=S0103-84782015000100163 $>$. Accessed: Mar 23, 2017. doi: 10.1590/0103-8478cr20131212.

GONÇALVES, R.P.M. et al. Intra-abdominal pressure in dogs. Pesquisa Veterinaria Brasileira, v.31, n.9, p.812-816, 2011. Available from: $<$ http://www.scielo.br/scielo.php?script=sci_arttext\&pid=S0100736X2011000900014>. Accessed: Mar 23, 2017. doi: 10.1590/S0100736X2011000900014

HONG, J. et al. Prospective study of the incidence and outcome of intra-abdominal hypertension and the abdominal compartment syndrome. British Journal of Surgery, v.89, n.5, p.591-596, 2002. Available from: <https://www.ncbi.nlm.nih.gov/pubmed/11972549>. Accessed: Mar 23, 2017. doi: 10.1046/j.1365-2168.2002.02072.x.

HUNTER, J.; DAMANI, Z. Intra-abdominal hypertension and the abdominal compartment syndrome. Anaesthesia, v.59, n.9, p.899-907, 2004. Available from: <https://www.ncbi.nlm.nih.gov/pubmed/23673399>. Accessed: Mar 23, 2017. doi: 10.1007/s00134-013-2906-z.

JAPIASSÚ, A.M. et al. Measurement of intra-abdominal pressure in the intensive care unit. The opinion of the critical care physicians. Revista Brasileira de Terapia Intensiva, v.19, n.2, 2007. Available from: $\quad<$ http://www.scielo.br/scielo.php?script=sci arttext\&pid=S0103-507X2007000200008 $>$. Accessed: Mar 23, 2017. doi: 10.1590/S0103-507X2007000200008.

JOUBERT,K.E. etal.Abdominal compartmentsyndrome in a dog with babesiosis. Journal of Veterinary Emergency and Critical Care, v.17, n.2, p.184-190, 2007. Available from: <http://onlinelibrary. wiley.com/doi/10.1111/j.1476-4431.2006.00219.x/pdf>. Accessed: Mar 23, 2017. doi: 10.1111/j.1476-4431.2006.00219.x.

KLEIN, W. et al. Metabolic response to feeding in Tupinambis merianae: circadian rhythm and a possible respiratory constraint. Physiological and Biochemical Zoology, v.79, n.3, p.593-601, 2006. Available from: <https://www.ncbi.nlm.nih.gov/pubmed/16691525>. Accessed: Mar 23, 2017. doi: 10.1086/502818.

LUI, F. et al. Abdominal compartment syndrome: clinical aspects and monitoring. Critical Care Clinics, v.23, n.3, p.415-433, 2007. Available from: $<$ http://www.sciencedirect.com/science/article/pii/S0749070407000358> Accessed: Mar 23, 2017. doi: 10.1016/j.ccc.2007.05.006.

MALBRAIN, M.L. Different techniques to measure intra-abdominal pressure (IAP): time for a critical re-appraisal. Intensive Care Medicine, v.30, n.3, p.357371, 2004. Available from: বhttps:/www.ncbinlm.nih.gov/pubmed/14730376>. Accessed: Mar 23, 2017. doi: 10.1007/s00134-003-2107-2.

MALBRAIN, M.L. et al. Results from the international conference of experts on intra-abdominal hypertension and abdominal compartment syndrome. I. Definitions. Intensive Care Medicine, v.32, n.11, p.17221732, 2006. Available from: <https://www.ncbi.nlm.nih.gov/pmc/ articles/PMC439406/> . Accessed: Mar 23, 2017. doi: PMC439406.

MALBRAIN, M.L.; DEEREN, D.H. Effect of bladder volume on measured intravesical pressure: a prospective cohort study. Critical Care, v.10, n.4, p.1, 2006. Available from: <https://www.ncbi.nlm.nih.gov/pmc/ articles/PMC1750998/>. Accessed: Mar 23, 2017. doi: PMC1750998.

MARSHALL, J.C. et al. Multiple Organ Dysfunction score: a reliable descriptor of a complex clinical outcome. Critical Care Medicine, v. 23, n.10, p.1638-1652, 1995. Available from: <http:// journals.lww.com/ccmjournal/Abstract/1995/10000/Multiple_Organ Dysfunction_Score_A_reliable.7.aspx $>$. Accessed: Aug 31, 2017.
MARTINEZ-JIMENEZ, D.; HERNANDEZ-DIVERS, S.J. Emergency care of reptiles. Veterinary Clinics of North America: Exotic Animal Practice, v.10, n.2, p.557-585, 2007. Available from: $<$ https://www. ncbi.nlm.nih.gov/pubmed/17577563>. Accessed: Mar 23, 2017. doi: 10.1016/j.cvex.2007.02.003.

MUNSTERMAN, A.S.; HANSON, R.R. Comparison of direct and indirect methods of intra-abdominal pressure measurement in normal horses. Journal of Veterinary Emergency and Critical Care, v.19, n.6, p.545-553, 2009. Available from: <https://www. ncbi.nlm.nih.gov/pubmed/20017760>. Accessed: Mar 23, 2017. doi: 10.1111/j.1476-4431.2009.00482.x.

RABELO, R.C.; ZORZELLA, M.M. Síndromes Compartimentais. In: RABELO, R.C. Emergências de Pequenos Animais Condutas Clínicas e Cirúrgicas no Paciente Grave. Rio de Janeiro: Elsevier, 2012. Cap. 22, p. 347-367.

RICHARDSON, J.D.; TRINKLE, J.K. Hemodynamic and respiratory alterations with increased intra-abdominal pressure. Journal of surgical research, v.20, n.5, p.401-404, 1976. Available from: $<$ https://www.ncbi.nlm.nih.gov/pubmed/933497>. Accessed: Mar 23, 2017. doi: 933497.

RISIN, E. et al. A new technique of direct intra-abdominal pressure measurement: a preliminary study. The American Journal of Surgery, v.191, n.2, p.235-237, 2006. Available from: $<$ https://www. ncbi.nlm.nih.gov/pubmed/16442952>. Accessed: Mar 23, 2017. doi: 10.1016/j.amjsurg.2005.07.038.

RIVERA, S. Health assessment of the reptilian reproductive tract. Journal of Exotic Pet Medicine, v.17, n.4, p.259-266, 2008. Available from: $<$ http://www.sciencedirect.com/science/article/pii/S1557506308001225>. Accessed: Mar 23, 2017. doi: 10.1053/j.jepm.2008.07.003.

SAGGI, B.H. et al. Abdominal compartment syndrome. Journal of TraumaInjury Infection e Critical Care, v. 45, n. 3, p. 597-609, 1998. Available from:<vidsp.uk.ovid.com/sp-3.26.1a/ovidweb.cgi>. Accessed:Aug 31, 2017.

SCHACHTRUPP, A. et al. Evaluation of two novel methods for the direct and continuous measurement of the intra-abdominal pressure in a porcine model. Intensive Care Medicine, v.29, n.9, p.1605-1608, 2003. Available from: <https://www.ncbinlm.nih.gov/pubmed/12920511>. Accessed: Mar 23, 2017. doi: 10.1007/s00134-003-1847-3.

SCHEPPACH, W. Abdominal compartment syndrome. Best Practice \& Research Clinical Gastroenterology, v.23, n.1, p.25-33, 2009. Available from: <http://www.sciencedirect.com/science/article/pii/ S1521691808000899>. Accessed: Mar 23, 2017. doi: 10.1016/j. bpg.2008.11.009.

SMITH, S.E.; SANDE, A.A. Measurement of intra-abdominal pressure in dogs and cats. Journal of Veterinary Emergency and Critical Care, v.22, n.5, p.530544, 2012. Available from: \https:/www.ncbi.nlm.nih.gov/pubmed/23110567>. Accessed: Mar 23, 2017. doi: 10.1111/j.1476-4431.2012.00799.x.

STAHL, S.J. Pet lizard conditions and syndromes. Seminars in Avian and Exotic Pet Medicine: Elsevier, 2003. p.162-182. Available from: $<\mathrm{http}: / /$ www.exoticpetmedicine.com/article/S1055-937X(03)80021-X/ abstract>. Accessed: Mar 23, 2017. doi: 10.1053/saep.2003.00019-7.

SYKES, J.M. Updates and practical approaches to reproductive disorders in reptiles. Veterinary Clinics of North America: Exotic Animal Practice, v.13, n.3, p.349-373, 2010. Available from: <https://www. ncbi.nlm.nih.gov/pubmed/20682424>. Accessed: Mar 23, 2017. doi: 10.1016/j.cvex.2010.05.013. 